\title{
Jesus: 'n Geloofsgeneser?
}

\author{
Johan Ayres \& Andries van Aarde \\ Departement Nuwe-Testamentiese Wetenskap (Afd A)
}

Universiteit van Pretoria

\begin{abstract}
Jesus: A faith-healer?

How are we in a modern age to understand the healing wonders of Jesus in the gospel? How must exorcism be understood? The intention of this paper is to indicate that Jesus' exorcisms are to be understood against the background of the stress factors in the first-century Mediterranean world. The propaganda motive, as well as the competitive milieu in which the texts originated, must be kept in mind when interpreting the healings of Jesus. Jesus' exorcisms are embedded in the structure and institutions of his time. The various institutions in the first-century Mediterranean world must not be understood as separate from one another: they are in fact embedded in each other. The healings of Jesus should be understood as healings of empowerment. Jesus empowers people to cope. He gives authentic meaning to peoples' lives on account of their experience of God's presence.
\end{abstract}

\section{NAVORSINGSPROBLEEM}

Hierdie studie sal poog om aan te toon watter faktore aanleiding gegee het tot stres in die eerste-eeuse Mediterreense wêreld. Jesus se eksorsismes word verklaar aan die hand van hierdie stres, aangesien die genesings/eksorsismes van Jesus ingebed is in die struktuur en instellings van sy tyd. Demone is in die destydse leefwêreld gesien as die teenpool van God en stresverligting het beteken om van hierdie demone bevry te word.

In hierdie studie word gepoog om aan te toon dat Jesus se genesings in 'n moderne samelewing en in hedendaagse Afrikaans omskryf kan word met die term wat bemagtigingsgenesings genoem word. Jesus 'bemagtig' mense wat geknak het onder stres, om te oorleef. Hy gee nuwe sin en betekenis aan mense se lewe. Die genesings van Jesus is nie wondergenesings in die sin van 'n bonatuurlike ingryping van God in die fisiese

* Hierdie artikel is 'n verwerking van die resultate van die MA (Teol)-verhandeling, 'Jeaus - 'n Geloofsgeneser?', Departement Nuwe-Testamentiese Wetenskap, Fakulteit Teologie (Afd A), Universiteit van Pretoria, onderieiding van prof dr A G van Aurde. 
wêreld nie; dit is eerder God se ingryping in die sosiale leefwêreld en lewens van mense. ' $n$ Wonder is nie God se periodieke inbreuk in 'n geslote natuurlike bestel is nie. Dit is eerder die permanent verskuilde, tog immer en onophoudelike hartklop van die natuurlike. Dit is teenwoordig vir hulle wat dit deur die oog van geloof sien en met die oor van geloof hoor (kyk Crossan 1996:88, 96).

\section{LEES MET 'N ANTIEKE BRIL}

\subsection{Die betekenis van taal is altyd konteks- en kultuurgebonde}

Alle taal, mondelings of geskrewe, ook die taal van die Bybel, kry betekenis op grond van die gemeenskapsisteem en kulturele konteks waarin dit ontstaan het (Malina 1993:xi). Selfs kunswerke en argitektuur is ingebed in 'n bepaalde sosiale wêreld (kyk Horsley 1994:91). Om die Bybel dus vandag korrek te interpreteer is dit belangrik dat ons sal besef dat die Bybel ' $n$ antieke versameling dokumente is, ' $n$ bundel wat in ' $n$ ande- wêreld ontstaan het as die wêreld wat ons ken. Die eerste-eeuse Mediterreense mense het anders geleef en anders gedink as wat ons aan die einde van die twintigste eeu doen. Hierdie leefwêreld en denkwêreld van die Mediterreense mense het uiteraard in hulle gesikrifte neerslag gevind.

By die lees van die Bybel vandag moet ook in gedagte gehou word dat die outeurs van die Bybel nie die bedoeling gehad het om 'n versameling geskrifte te skryf met ewig geldende waarhede vir alle eeue wat sou volg nie. Die Bybelskrywers het hulle ervarings, hulle belewenisse van God en hulle getuienisse oor God opgeteken. So het die evangelieskrywers vanuit hulle denkwêreld hulle ontmoeting met en hulle interpretasie vari die tradisies oor Jesus neerslag laat vind in hulle geskrifte.

Ons moet nie vandag die fout maak om anachronisties en met 'n tegnologieswetenskaplike bril na Jesus se wonderwerke, genesings en eksorsismes te kyk, deur te vra 'Hoe kon dit gebeur?' nie, of 'Is daar sulke dinge soos demone?' nie. Hierdie vrae is irrelevant. Die vraag moet eerder wees 'Wat het hierdie mense geglo?' of 'Hoe het hulle hulle geloof beleef?' Hierdie vrae sal dan die moderne Bybelleser daartoe lei om ' $n$ idee van die destydse wêreldbeeld te vorm.

\subsection{Eksterne kragte}

By die lees van tekste moet hulle ontstaanswêreld in gedagte gehou word. Ons moenie die wonders en die nood van antieke mense deur ons Westerse bril lees nie. Die wonders wat in die Bybel opgeteken is en die eerste-eeuse Mediterreense mense se nood, moet verstaan word deur die insigte vanuit die kultuurantropologie in ag te neem.

Mense se nood is destyds vertig deurdat 'n 'eksterne krag' (God) beheer kry oor 'n ander eksterne krag wat die nood veroorsaak het. Dit word gedoen deur agente; in die 
Grieks-Romeinse wêreld die 'theios aner' ('n 'held' in die vorm van 'n god-mens, soos Herakles, Asklepius of Priapus), en in die Joodse wêreld gesante van God, mense wat God se gees besit (profete, konings, priesters). Satan het ook agente in diens, byvoorbeeld die demone, wat van 'n persoon besit kan neem. Vir die Jode was die uitnemendste van hierdie agente God se Messias (1 Henog 53:3-5; 54:4-6; Test Levi 18: 12). In die nh-monargale periode, wanneer daar gedink word aan dié Messias, kry Messias 'n genesersfunksie (kyk Rousseau 1992:30-31). Maar almal assosieer Jesus nie met die Mestias nie. Vir Jesus se opponente (Fariseërs) was Hy 'n agent van die bose, Beelsebul (Matt 12:22-32).

\subsection{Die begrip 'eksorsisme'}

Eksorsisme is die daad deur 'n eksorsis, waarin die vyandige entiteit(e) beveel word om die besete persoon te verlaat en nooit weer terug te keer nie. Ten einde Jesus se genesings en eksorsismes te verstaan, moet 'n mens besef dat die cerste-eeuse Mediterreense mense geglo het dat hulle hulle leefruimte en omgewing met onsigbare geeste en demone gedeel het. Verskeie Nuwe-Testamentiese tekste is bewys hiervan: 1 Korintiërs 10:20-21; 12:10; 2 Korintiërs 4:4; Efesiërs 1:21; 2:2; 6:12, 6.

Die evangelies is antieke literatuur en Bybellesers vandag moet onthou dat hulle besockers op reis in 'n antieke wêreld is. Palestina het aan twee werelde behoort: Nabye- en Midde-Ooste, en Oostelik-Mediterreens. Die Judaisme van Jesus se tyd is beinvloed deur die Babiloniese en Griekse kultuur, deur die Egiptiese beskawing en deur Hellenisme. Die eksorsismes van Jesus moet teen hierdie agtergronde bestudeer word (Rousseau 1992:16).

Die moderne Bybelleser moet in gedagte hou dat eksorsismes noodwendig die geloof in die bestaan van onsigbare, vyandige entiteite en die fenomeen van besitneming vooronderstel. Vyandige besetenheid kan gedefinieer word as die besetting van 'n persoon deur 'n vyandige en onsigbare entiteit. Hierdie besetenheid kan permanent, met tussenposes, of tydelik wees. Wanneer duiwels uitgedryf word, glo die beangste besetene dat die corsaak van die probleem verdwyn het. Hierdie cortuiging word deur die geneser bevestig en aangemoedig deur die besetene se sosiale kring. Dit verander die besetene se gedrag van vrees na kalmte. Wat het verander? Die aanvanklike lewensprobleme mag (of mag dalk nie) steeds teenwoordig wees, maar die cens besetene se persepsie ten opsigte van die probleme het verander (Pilch 1995:330).

\section{4 'n Kompeterende milieu}

By die lees van die genesingswonders moet ' $n$ mens ook die kompeterende milieu waarin die tekste ontstaan het, in aanmerking neem. Daar moet in gedagte gehou wor hierdie eksterne kragte in kompetisie was met mekaar. Die skare het met corgaw. 
hierdie kompetisie deelgeneem. Vandaar die kontroverse tussen Jesus en die Fariseërs in die genesingsperikope en die skare wat Jesus se gesag hoër as dié van die Fariseërs ag (kyk Matt 7:28-29).

In hierdie kompeterende milieu moet die propagandamotief ook in gedagte gehou word by die ontstaan van 'n teks, aangesien die bou van legendes op hierdie manier ontstaan het. Dit is belangrik om te weet dat-daar destyds ook baie ander wonderdoeners naas Jesus was. Hierdie wonderdoeners word teenoor mekaar afgespeel en vanuit die gesigspunt van die evangeliste moet Jesus hoër gestel word as ander wonderdoeners (vgl Vermes 1973:58-82). Funk (1996:253) sê dat die verskillende tipes wondervertellings by die Christelike repertoire gevoeg is om Jesus in kompetisie te bring met ander charismatiese wysheidsleraars, eksorsiste en wonderdoeners.

In 'n wêreld waar daar ook ander wonderdoeners aktief was, was dit vir die vroeë kerk belangrik om Jesus as 'n wonderdoener te propageer. Wonderwerk-tradisies wat tot stand gekom het, is deur die vroee kerk gebruik in prediking, onderrig en sendingwerk onder die heidene ten einde mense te oorreed om in Jesus te glo (kyk Engelbrecht 1986:37). Om hierdie rede waarsku Funk (1996:58) dat dit belangrik is om (die historiese) Jesus te onderskei van die berigte wat oor Hom in die evangelies bewaar gebly het, aangesien daardie Jesus tot 'n groot mate 'n konstruksie op grond van die geloof van sy eerste aanhangers was.

Hierdie propagandamotief beteken dat Jesus in die Nuwe Testament geteken word as in kompetisie met die Griekse gode en ander wonderwerkers (kyk Funk \& The Jesus Seminar 1998:547). Dieselfde propagandamotief blyk ook duidelik uit Matteus se vertelling van die silwermuntstuk in die vis se bek (Matt 17:24-27). Van Aarde (1994b: 226) is van oordeel dat een van Matteus se motiewe met hierdie vertelling is om Jesus se superioriteit oor die gode van die see aan te toon.

Verder is dit cok belangrik om in gedagte te hou dat ons oor geen enkele woord of storie van Jesus beskik, wat nie terselfdertyd daarin die geloofsoortuiging van die eerste Christene ingebed het nie. Vorster (1986:48) sien die wondertradisies in die Nuwe Testament as propaganda vir die geloof in Jesus en in die Christendom. Die evangelieskrywers vertel wel van 'n tydperk toe Jesus geleef het, maar teen die tyd toe hulle geskryf het, het die materiaal wat hulle gebruik het, alreeds 'n corleweringsproses deurloop. Die verhale van Homerus was wyd gerepeteer gedurende die Hellenistiese tydperk - dus sou die evangelieskrywers deeglik bewus gewees het van dit wat die Griekse gode kon doen (Funk 1996:253). Hierdie feit moet altyd by die lees en interpretering van tekste in gedagte gehou word. 


\section{DIE MEDITERREENSE SAMELEWINGSTRUKTUUR}

Die Mediterreense samelewingstruktuur het hoofsaaklik uit die volgende instellings bestaan:

* Familie (hoogste prioriteit);

* Politiek;

* Ekonomie ;

* Godsdiens.

In die Mediterreense wêreld kan die godsdienstige, familiaie, politieke en ekonomiese strukture nie sonder meer in aparte kompartemente ingedeel word nie (Van Aarde 1994a:89). Die familiestruktuur het die hoogste prioriteit geniet, waarby die politiek, ekonomie en godsdiens ingebed was. 'n Persoon se familie het sy of haar status in die gemeenskap bepaal, maar dit het ook gedien as die primêre ekonomiese, godsdienstige, opvoedkundige en sosiale netwerk. Die verbreking van familiebande het ook verlies van hierdie belangrike netwerk beteken (Malina \& Rohrbaugh 1992:100101).

Die feit dat godsdiens nie 'n duidelik afgebakende terrein teenoor, byvoorbeeld, die mediese terrein was nie, is af te lei uit die feit dat dit algemene praktyk was om na profete (godsdienstige personeel) toe te gaan vir genesing (2 Kon 5:1-3). In teenstelling hiermee funksioneer die instellings in Eerste-wêreldlande vandag los van mekaar, byvoorbeeld: Die president van Amerika is nie die monarg van die land omdat hy hoof van ' $\mathrm{n}$ (spesifieke) familie is nie.

Toegepas op die regswese kan die andersheid van 'n familie soos volg geillustreer word: Indien 'n regstoerekenbare seun geld sou verduister in ons tyd, sal 'n regter die betrokke persoon uit die samelewing 'verwyder' deur hom tronkstraf op te lê. Dit sal familiestres teweegbring, maar dit sal nie vreemd wees as die pa sy seun in die tronk gaan besoek nie. In teenstelling hiermee, in die Mediterreense wêreld, as die seun geld van ' $n$ familielid sou steel, is hy beskou as 'n 'agent van die bose' en geostraseer. Dus het 'n eksterne krag veroorsaak dat 'n noodsituasie ontstaan. Dieselfde geld met betrekking tot siekte. Iemand is siek, dus het eksterne kragte 'n invloed op die persoon uitgeoefen. Binne die eerste-eeuse Mediterreense leefwêreld is gemeen dat bose magte vir ellendes soos siektes verantwoordelik is. In Israel sou dit beteken dat geoordeel is dat God toelaat dat die bose die lewe van 'n siek mens beset. So 'n persoon kan dus beskou word as ' $n$ agent vir die bose, en daar kan in die samelewing verwag word dat so 'n persoon onder sekere omstandighede deur sy of haar familie verstoot moet word. Die onderskeid tussen instellings het nie in die Mediterreense wêreld gegeld nie. 
Die grootste nood destyds lê by onaanvaarbaarheid, verwerping deur jou familie. In teenstelling hiermee het ons in die Eerste-wèreld die verskillende instellings. grootliks van mekaar geskei en sodoende ook ' $n$ onderskeid met betrekking tot die nood begin tref. So byvoorbeeld is die nood in die kerk die sonde, terwyl die nood in die ekonomie materiële gebrek is.

\subsection{Familie}

Die Mediterreense familielewe is patriargaal georiënteer, met die vader as die be-langrikste figuur binne die eerste-eeuse familie. Die manlike gesinshoof het absolute gesag or sy vrou, kinders, slawe en ander afhanklikes gehad. Dit was die vader se taak om sy gesin in die openbaar (ook wat die kultus betref) te verteenwoordig en om hulle goeie naam te beskerm. Dit illustreer die ineengevlegtheid van die familiale struktuur met die godsdienstige lewe.

Die ineengevlegtheid tussen familie, godsdiens en regspraak is duidelik uit die feit dat 'n Israelitiese vrou onder normale omstandighede nie as getuie in 'n hof kon optree nie en ook nie religieuse take kon vervul nie (Van Aarde 1994a:41). Die ineengevlegtheid is ook duidelik te sien uit die feit dat die sinagoge die sentrum was vir die godsdiens en sosiale lewe van die Jode aangesien dit gedien het as skool, vergaderplek en regsbank. Aanvanklik was synagogai nie geboue soos kerkgeboue vandag nie, maar plaaslike dorpsvergaderplekke binne die huise van mense (kyk Horsley 1994: 113).

Ongeveer 90\% van die inwoners van eerste-eeuse Palestina was boere en het in die dorpies gewoon, wat dikwels nedersettings rondom grotere stede was. Die leiers van die dorpies was die familiehoofde (oudstes), wat openbare eer besit het. Alhoewel Matthews (1988:259) sê dat 'n sinagoge gedurende die Nuwe-Testamentiese tyd waarskynlik in elke Palestynse stad en dorpie van enige grootte bestaan het, dui argeologiese getuienis daarop dat aparte sinagoges as 'gebedshuise' eers in die derde eeu n $\mathrm{C}$ ingerig of gebou is. Dit is in elk geval te betwyfel of klein dorpies hulle eie torarol of rabbi gehad het. Die prominente familiehoofde het waarskynlik ook die godsdiensoefening gelei, soos wat hulle ook die politieke sake gereël het (Van Aarde 1994a:102). Dit illustreer die ineengevlegtheid tussen familiale struktuur, politiek en godsdiens. Dit verklaar ook die vyandigheid van baie klein dorpies jeens Jesus. Jesus kom daar aan met 'n skare volgelinge, afkomstig uit veral die kleinboerderygemeenskap, dikwels bestaande uit 'onreines' en bedreig op hierdie manier die leiersposisies van die plaaslike familiehoofde (Van Aarde 1994a:102; vgl ook Joh 11:47-48).

\subsection{Politiek}

Alle byeenkomste van die dorp se inwoners, hetsy vir besigheid, feeste of gebed, het op die markplein, 'stadsaal,' of kamer van een van die groter huise plaasgevind (Van 
Aarde 1994a:102). Ook sulke byeenkomste (dit wil sê 'politieke' vergaderings) is as synagogai bestempel (kyk Chiat 1981:50; Meyers 1981:62). Die plek waar die funksie verrig was, het dus nie, soos vandag, van mekaar verskil nie.

Mag ek politiek en godsdiens meng? Hierdie vraag getuig van 'n tipiese Eurosentriese, moderne denke en verstaan van die samelewingstruktuur. Persone in die eersteceuse Mediterreense kultuur sou nie hierdie vraag gevra het nie, want godsdiens en politiek was vir hulle ineengevlegte sake gewees. Hierdie saak word geillustreer deur verskeie gedeeltes in die evangelies waar 'tollenaars' en 'sondaars' saam genoem word (vgl bv Matt 9:10-11; 11:19): hulle was beide 'verraaiers.' Tollenaars was 'verraaiers,' want hulle het met die Romeinse owerheid of Romeinse 'kliënte-regeerders' saamgewerk. Die goddeloses was ook 'verraaiers,' want hulle het God, wat Israel verlos het, verraai. Daar was dus nie 'n duidelike onderskeid tussen godsdienstige verraad en politieke verraad in eerste-eeuse Judaisme nie (kyk Sanders 1985:178).

\subsection{Ekonomie}

Die ekonomie was eerstens in die familie ingebed, wat beide die produserende en verbruikerseenheid was. Aangesien die familie die produserende eenheid was, het 'n huwelik (wat beteken dat ' $n$ vrou uit die familie weggeneem word om in die bruidegom se huis opgeneem te word), tot gevolg gehad dat die verlies van die een huisgesin die wins van die ander huisgesin was. Daarom was 'n bruidsprys verlang om vir die verlies te kompenseer (vgl Malina \& Rohrbaugh 1992:100).

Daarbenewens was die ekonomie ook in die politiek ingebed, wat beteken het dat die politieke entiteit beheer gehad het oor die beweging en verspreiding van sekere goedere na en vanaf die stad, veral van kerninstellings: die paleis (en die weermag), die tempel (en die priesters), en die aristokrasie. Nêrens lees ons van terminologie wat op 'n aparte 'ekonomiese sisteem' dui nie.

Die tempel was nooit 'n godsdienstige instelling los van die politieke instellings nie. Daar kon 'n huishoudelike godsdiens gewees het wat deur' 'familiepersoneel' beheer is, en/of politieke godsdiens beheer deur 'politieke personeel,' maar godsdiens is nooit in 'n aparte lig gesien en beheer deur suiwer 'godsdienstige personeel' nie. Aanbidding was ook nie anders as dit wat by die huis gedoen is nie. Godsdiens was die betekenis wat gegee is aan die manier waarop die politiek en familiale sisteem in die praktyk grondgevat het (Malina \& Rohrbaugh 1992:138). Laasgenoemde paragraaf illustreer duidelik die ineengevlegtheid van die familiale struktuur, die ekonomie, die godsdiens en die politiek. 


\subsection{Godsdiens}

Godsdiens as 'n aparte, institusionele entiteit in die moderne sin van die woord het nie bestaan nie. Godsdiens was eerder 'n oorkoepelende betekenissisteem wat die politiek en die familie (asook hulle ekonomiese aspekte), in 'n ideologiese geheel verenig het. Godsdiens was die instrument waardeur die politiek en die familie gelegitimeer en geartikuleer is, maar ook mee gedelegitimeer en gekritiseer is. Die taal van die godsdiens is aan familieverhoudings ontleen (vader, seun, broer, suster, maagd, kind, beskermheer, genade, eer, vergewing, losprys ens), asook die politiek (koning, koninkryk, prinse van die wêreld, magte, verbond, wet ens). Godsdiens was deel van en was dus ingebed in bogenoemde strukture van die familie, die politiek en die ekonomie. Godsdienstige doelwitte, optrede, rolle, werkverskaffing, organisasie en sisteme van aanbidding is deur politieke en familiale oorwegings gelei, nie deur 'godsdienstige' orwegings nie (Malina \& Rohrbaugh 1992:138; kyk ook Van Aarde 1994a:89).

Volgens Malina \& Neyrey (1991a:73-74) was die basiese en primère sosiale eenheid waarmee hierdie diadiese persoon in verhouding was, die familie. Hulle leef vir hierdie groep waarin hulle ingebed is; sonder hierdie groep voer hulle 'n sinlose bestaan.

\section{VEROORSAKENDE STRESFAKTORE IN DIE MEDITERREENSE SAME- LEWINGSTRUKTUUR}

\subsection{Intrafamiliale konflik}

Davies (1995:107-109) gaan van die aanname uit dat baie van Jesus se volgelinge Hom begin volg het omdat Hy hulle genees het/demone uit hulle uitgedryf het. Dit is onwaarskynlik dat mense Jesus sou volg, hulle werkplek en families sou verlaat bloot omdat Hy hulle 'geroep' het. Hierdie rede waarom mense, veral uit die heidendom, Jesus begin volg het, word reeds gevind in 'n opmerking wat die kerkvader Origenes teenoor die Griekse filosoof Celsus gemaak het (kyk Van Aarde 1994b:209).

Wat was die mense wat Jesus gevolg het, se motiewe? Waarom het hulle Jesus gevolg? Davies (1995:81) beskou intrafamiliale konflik as een van die hoofoorsake vir duiwelbesetenheid. Dit kan dus met redelike sekerheid gesê word dat persone uit wie daar duiwels uitgedryf is, en wat teruggekeer het na hulle familie sonder dat die konfliksituasie binne die familie verander het, nie 'n groot moontlikheid op langtermyn sukses/genesing gehad het nie. Jesus se oplossing hiervoor was dat Hy daardie mense aangemoedig het om sulke situasies in die toekoms te vermy, deur hulle aan te moedig om hulle families te verlaat en deel te word van 'n surrogaatfamilie, met God as die Vader (Evang Tomas 99; Mark 3:32-35; ook ondersteun deur QLuk 9:59-62; 12:51- 
53; 14:26-27; Mark 10:28-30). Jesus het mense aangemoedig om hulle families te verlaat, 'n feit wat verstaanbaar is in die lig van die omstandighede wat veroorsaak het dat mense na Jesus toe gekom het vir genesing en eksorsisme.

Jesus se uitsprake moet verstaan word binne die konteks van mense uit wie Hy demone gedryf het, mense wat onder die druk verkeer het dat hulle deur hulle families om een of ander rede verwerp sou word, en gevolglik ook 'n innerlike stryd gevoer het.

Sommige van Jesus se uitsprake maak goeie sin slegs wanneer dit binne hierdie konteks gelees word, byvoorbeeld die Evangelie van Tomas 68-69a:

Jesus said: 'Congratulations to you when you are hated and persecuted; and no place will be found, wherever you have be persecuted.' Jesus said: 'Congratulations to those who have been persecuted in their hearts: they are the ones who have truly come to know the Father.'

(Funk \& Hoover 1993:512)

Elemente van hierdie Jesus-tradisie kom ook in die Spreuke-evangelie Q (kyk Luk 6:22-23) voor. Matteus (5:11) se interpretasie van hierdie tradisie moet teen die agtergrond van kontroversies met die sinagoge verstaan word. Die vervolgings waarna die passasie in die konteks van die historiese Jesus verwys, het waarskynlik nie uit die gemeenskap ontstaan op grond van leerstellige gronde nie; die vervolging het waarskynlik binne families voorgekom, en gevolglik innerlike foltering teweeggebring. Verskeie uitsprake van Jesus moet verstaan word teen die agtergrond daarvan dat baie van sy volgelinge voormalige lede van families was wat onderlinge konflik ervaar het en nou in 'n surrogaatfamilie opgeneem is. Wat hier dus moontlik kon gebeur het, is dat Jesus so 'n situasie 'genees' het. Waar Jesus mense aanspoor om hulle familie te haat en te verlaat, doen $\mathrm{Hy}$ dit teen die agtergrond dat hulle met wie Hy praat, mense was wat alreeds ernstige familiekonflikte beleef het. Sommige van hulle het alreeds hulle moeders, vaders, skoonma ensovoorts 'gehaat'. 'Familie' in hierdie konteks dui op biologiese families sowel as huweliksverhoudings (Davies 1995:110). In Jesus vind hulle dus 'n nuwe (surrogaat)-familie.

Jesus het waarskynlik mense uitgestuur op sendings om 'te genees en duiwels uit te dryf in sy naam,' maar hulle effektiwiteit sou direk proporsioneel gewees het aan en afhanklik gewees het van Jesus se reputasie as 'n geneser. Op daardie tydstip was die naam 'Jesus' 'n algemene naam en sou nie op sigself 'magiese effektiwiteit' gehad het nie. Indien Jesus 'n reputasie gehad het as 'n geneser en eksorsis, is dit moontlik dat sy verteenwoordigers onder daardie sambreel gewerk het om namens Hom te genees en duiwels uit te dryf (Davies 1995:111). 
Davies (1995:69) beskou Jesus dus as 'n geloofsgeneser. Hiervolgens sou navolging van Jesus neerkom op geloof in die krag van die geneser. Gevalle wat deur geloofsgenesing genees of verlig is, is gewoonlik psigosomaties van aard. Davies is van oordeel dat so 'n geloofsgeneser slegs effektief sal wees met betrekking tot psigosomatiese ongesteldhede. Davies (1995:69-70) gebruik hiervoor die term 'verskuilde ongesteldheid,' ook bekend as 'verskuilde histerie' en 'verskuilde neurose' (senuweesiekte).

'n Verskuilde ongesteldheid kan ontstaan waar 'n persoon skuldig voel oor 'n bepaalde aksie, maar nie skuld wil aanvaar nie, en dit internaliseer. Daardie geinternaliseerde skuld manifesteer dan in 'selfstraf' soos blindheid, verlamming, of dermatitis (velontsteking). Traumatiese ondervindings kan aanleiding gee tot 'verskuilde ongesteldheid' indien dit onderdruk word en weer verskyn as fisiese simptome. Die uitstaande kenmerk van hierdie ongesteldheid is 'n verandering of verlies van fisiese funksie wat dui op fisiese ongesteldheid, maar wat eintlik 'n uitdrukking is van 'n psigologiese konflik of behoefte.

Die pasiënt kan tweërlei voordeel trek uit hierdie verskuilde ongesteldheid: Eerstens verkry die persoon primêre voordeel, byvoorbeeld, ná 'n argument kan innerlike konflik oor die uitbarsting van woede manifesteer as 'stomheid,' of as 'verlamming' van die arm; of as 'n persoon 'n traumatiese gebeurtenis gesien het, kan 'n konflik oor die erkenning van daardie gebeurtenis uitgedruk word as 'blindheid'. In hierdie gevalle het die simptoom 'n simboliese waarde wat 'n verteenwoordiging en spesifieke oplossing is van die onderliggende psigologiese konflik. Tweedens verkry die persoon sekondêre voordeel deur die vermyding van 'n bepaalde aktiwiteit wat skadelik is, byvoorbeeld, met 'n verlamde arm kan 'n soldaat nie 'n geweer hanteer nie. Die normale ouderdom vir verskuilde ongesteldheid is adolessensie of vroeë volwassenheid en is gewoonlik van korte duur.

Somatiese ongesteldheid is 'n verwante sindroom, met die volgende kenmerke: herhaalde en veelvoudige somatiese klagtes, wat etlike jare duur, waarvoor mediese hulp gesoek is, maar wat waarskynlik nie veroorsaak word deur 'n fisiese ongesteldheid nie. Somatiese ongesteldheid het verskuilde of pseudo-neurologiese simptome wat gewigsverlies, stomheid, doofheid, blindheid, verlamming, spierverswakking en uitermatige menstruele bloeding insluit. Somatiese ongesteldheid is in wese 'n vorm van verskuilde ongesteldheid wat oor 'n langer periode plaasvind. Stomheid, doofheid, verlamming (geheel of gedeeltelik), en uitermatige menstruele bloeding is die oorgrote meerderheid van gevalle wat Jesus genees het. Dit bring Davies (1995:67-73) tot die slotsom dat die tipe persone wat deur Jesus genees is, waarskynlik die ongesteldhede gehad het wat hierbo bespreek is.

Crossan (1996:81) stem saam met Davies oor die feit dat 'geloof genees'. In die genesingstempel van Maria in Lourdes, Frankryk, is die baie stelle krukke wat daar agtergelaat is, die stille getuienis van mense wat daar genees is. Tog is kunsmatige lede- 
mate opvallend afwesig - geen getuienis van parapleë met geamputeerde ledemate wat herstel is nie. Dus: Geloof genees! Sekere persone kan van sekere siektes onder sekere omstandighede genees word: 'n heiden by Epidaurus in Griekeland of Pergamum in Turkye (genesingstempels van die heidense god Asklepius), 'n Christen by Lourdes in Frankryk of Fatima in Portugal (genesingstempels van Maria, die moeder van Jesus), 'n Hindu by Benares, ensovoorts. So het sommige mense na Jesus toe gekom om genees te word en hulle is genees.

Crossan (1996:81) maak melding van kunsmatige ledemate wat opvallend afwesig is in die antieke genesingstempels. Wat hedendaagse Suid-Afrika betref, gee Bate (1995:30-33) 'n voorbeeld hiervan in sy bespreking van 'n genesingsdiens onder die opskrif 'Miracle Tent Crusade'. Bate gee voorbeelde van persone wat daarop aanspraak maak dat hulle by ' $n$ byeenkoms naby Durban genees is: 'n persoon wat 'n nieroorplanting nodig gehad het, 'n persoon met artritis, 'n persoon met gedeeltelike gehoorverlies, 'n persoon met epilepsie. Maar dan sluit hy die beskrywing van die byeenkoms af deur te sê: Two badly crippled men are brought last of all. They are prayed for and left lying on the stage almost till the end of the proceedings. There has been no miracle for them. They are led away after their ordeal (kyk Bate 1995:33).

\subsection{Druk van die Romeinse bewind/belastingheffings}

Verskillende mense reageer verskillend op 'n stresvolle situasie. So sal 'n klein persentasie studente vandag byvoorbeeld 'n veluitslag ontwikkel voor 'n groot eksamen (psigosomatiese dermatitis), terwyl ander studente geen simptome sal toon nie. Net so het sommige eerste-eeuse Palestyne 'oorleef' onder die druk van die Romeinse bewind en onder die Judese belastingheffings, terwyl ander psigosomaties siek geword het. Bewyse bevestig dat Jesus sommige van laasgenoemde genees het. Dus kan Jesus se genesings beskryf word as psigoterapeuties van ard. Meeste genesings is! (Davies 1993: 2; kyk ook Malina \& Rohrbaugh 1992:375-376 i v m belastingheffings).

\subsection{1 'Melaatsheid'}

Die veluitslag waarvan in bostaande paragraaf gepraat word en wat in die Afrikaanse Bybel vertaal word met 'melaatsheid,' is nie dieselfde as die moderne siekte Hansen sindroom nie. Hansen sindroom was wel bekend in die Grieks-Romeinse wèreld, maar daar is daarna verwys as elefas of elefantiasis en nie as lepra nie. Hansen sindroom word veroorsaak deur die basil (bakterie) Mycobacterium leprae. Dit is nie baie aansteeklik nie en dit het nie baie lank voor Jesus se tyd in die Mediterreense gebied bestaan nie, waarskynlik nie voor 62 v C nie (Davies 1995:68). 


\subsubsection{Verhoogde somatiese simptome ten spyte van die afwesigheid van fisiese ongesteldheid}

Hierbo het ons gesien dat verskillende mense verskillend op 'n stresvolle situasie reageer. Net so is sekere groepe mense meer daartoe geneig om verhoogde somatiese simptome te vertoon ten spyte van die afwesigheid van fisiese ongesteldheid: (a) persone met neurotisisme of diagnoseerbare persoonlikheidsongesteldhede (b) persone met chroniese psigopatologiese ongesteldhede, byvoorbeeld depressie-ongesteldhede (c) persone wat voortdurende lewensmoeilikhede ervaar, byvoorbeeld 'n lang periode van werkloosheid, voortdurende huwelikskonflik, of 'n onveilige woonbuurt (d) persone wat 'n akute episode van stres verwante psigologiese simptomologie beleef, byvoorbeeld die rou ná die dood van 'n geliefde (Depue 1986:36).

Davies (1995:73) beskou die volgende tekste as voorbeelde van verskuilde ongesteldheid, wat deur die eerste-eeuse Mediterreense mense verstaan is as duiwelbesetenheid:

* koors bestraf as 'n demoon (Luk 4:38-39);

* verlies aan beweging van ledemate (Mark 2:1-12);

* kromtrekking van die rug veroorsaak deur 'n demoon (Luk 13:10-12);

* blindheid (Mark 8:22-27);

* doofheid (Mark 7:31-37);

* blindheid en doofheid veroorsaak deur 'n demoon (Matt 12:22);

* demoniese besetenheid (Mark 1:21-28).

Ons vind hier verklaringsparadigmas waarin somatiese, sintuiglike- en identiteitsdissosiasie gekoppel word aan en verklaar word deur die hipotese van geloof in die bestaan van demone en duiwelbesetenheid. Dit is nie duidelik of siekte/afwykings altyd verstaan is as deur 'n demoon veroorsaak nie, maar dit is duidelik dat alle vorme van afwykings wel so verstaan kon word.

Die verskil tussen ons eietydse beoordeling van hierdie gevalle en die beoordeling in die tyd van die Nuwe Testament, is die verskil tussen ' $n$ 'realistiese' beeld van die situasie, naamlik dat die probleme ontstaan as gevolg van kragte buite die betrokke persone (demone), en 'n 'idealistiese' beskouing (ons beskouing), naamlik dat die probleme ontstaan as gevolg van interme kragte binne die betrokke persone. Hier sien ons die verskil tussen die mitologiese wêreldbeeld (waarvan dịe Bybel getuig) teenoor die moderne wetenskaplike wêreldbeeld. 
In lyn met Davies sê Vorster (1986:49) dat ons begrip van 'n gebeurtenis in die Nuwe Testament kan verskil van die begrip en belewenis van die eerste-eeuse Mediterreense persoon, vir die eenvoudige rede dat ons begrip van die realiteit gebaseer is op ons moderne tegnologiese kennis van die wèreld en ons vanuit hierdie perspektief lees. Daarom waarsku hy dat ons nie die eerste-eeuse Mediterreense mens moet beskou as ons tydgenoot nie (Vorster 1986:49).

\section{VEROORSAKENDE FAKTORE VAN DUIWELBESETENHEID}

\subsection{Sosiale stres}

Sosiale stres kan veroorsaak word deur verskeie faktore, soos byvoorbeeld klassekonflik wat 'n oorsprong in ekonomiese uitbuiting het, etikettering, en 'koloniale oorheersing' (kyk Kiev 1964:135-137, 204-205, 262-263; Lewis 1971:35; Bourguignon 1976: 53-54; Van Eck 1995:309). De Villiers (1986:27) beskryf die omstandighede van die cerste-eeuse kleinboer as 'n 'diep gevoel van onsekerheid en vervreemding'. ' Dit kondisioneer mense psigologies en skep 'n gunstige teelaarde vir wondergenesings.

\subsubsection{Ekonomiese uitbuiting}

Die gemiddelde kleinboer en sy gesin kon so min as $20 \%$ van hulle jaarlikse opbrengs or gehad het vir eie gebruik en corlewing (vgl Malina \& Rohrbaugh 1992:375-376). In die geval van boere wat nie hulle eie grond besit het nie, maar gehuur het, was die persentasie uiteraard nog laer. Bourguignon (1976:53-54) sien in hierdie sosiale spanning wat teweeggebring word deur ekonomiese uitbuiting en belastingheffings, 'n moontlike oorsaak van duiwelbesetenheid. Davies (1993:2) se siening is in ooreenstemming hiermee as hy sê dat sommige eerste-eeuse Palestyne wel onder die druk van die Romeinse bewind en onder die Judese belastingheffings kon oorleef ('cope'), terwyl sommige psigosomaties siek geword het.

Die Joodse kleinboere was tiendes van hulle opbrengste asook die eerstelinge van die oes verskuldig (Horsley \& Hanson 1985:53). Onder die Persiese en Hellenistiese bewind was belastings ook aan die imperiale bewind betaalbaar. Die Romeine het, bo en behalwe die tiendes en offers aan die tempel verskuldig, ook belastings gehef, wat meegebring het dat die kleinboere dubbele belasting betaal het, waarskynlik meer as 40\% van hulle opbrengs (Horsley \& Hanson 1985:56). Oakman (1986:72) noem bykomend hierby ook belasting aan Herodes, prokurators en grondeienaars, wat kleinboere met $20 \%$ van hulle aanvanklike oes gelaat het. 


\subsubsection{Etikettering}

Voorbeelde van etikettering is legio in die sinoptiese evangelies. Etikettering kon positief of negatief wees (kyk Malina \& Neyrey 1988: 152-157 vir 'n volledige lys van positiewe en negatiewe etikette in Matteus). Daarom is dit belangrik om altyd te vra na die identiteit van die persone wat die beskuldigings maak. Davies (1995:31) wys aan die hand van Markus 3:22-30 daarop dat die etikettering 'demoon' (negatief) of 'gees' (positief) van die perspektief van die toeskouer afhang. Deur sommige groepe is Jesus positief geëtiketteer ('Christus die Here' - Luk 2:11; 'groot profeet' - Luk 7:16; 'leermeester' - Mark 5:35; 'Seun van God' — Luk 1:35), en deur ander groepe negatief ('van Beëlsebul besete' - Mark 3:22; 'opstoker' - Luk 23:5) ensovoorts.

Negatiewe etikettering was kragtige sosiale wapens waarmee 'n persoon skade berokken kon word (kyk Malina \& Neyrey 1988:4). Negatiewe etikettering, komende van invloedryke persone, kon skade aanrig indien die betrokke etiket daartoe gelei het dat so 'n persoon deur die gemeenskap as 'uit plek uit' beskou is (kyk Malina \& Neyrey 1991b:99). Om die werklike gevaar van negatiewe etikettering te verstaan, moet die diadiese persoonlikheid van die persone in die Nuwe Testament in gedagte gehou word. Dit het saak gemaak wat ander mense van jou dink, en dit op sy beurt het verband gehou met eer en skaamte.

Negatiewe etikettering was bedoel om 'n persoon te beskuldig van afwykende gedrag. 'Afwykende gedrag' is dié gedrag wat deur die lede van 'n sosiale groep beskou word as gedrag wat hulle gemeenskaplike verstaan van orde in hulle gemeenskap versteur. Die 'afwykende gedrag' het dus afgehang van die mening van die persone wat die beskuldiging gemaak het, en is nie bepaal deur die metafisiese aard van die aangeleentheid nie. In die oë van die etiketteerders, genoem die agente van sensuur (kyk Malina \& Neyrey 1991b:102), is die geetiketteerde in so 'n mate uit plek dat dit 'n (negatiewe) herdefiniëring noodsaak.

\subsubsection{Koloniale oorheersing}

Palestina onder Herodes is deur die Romeine beskou as ager publicus populi Romani, eiendom van die Romeinse owerheid en 'beskikbaar' vir uitbuiting (Oakman 1986:67). Ten spyte daarvan dat die Romeine die Jode se grondreëlings en huweliksreèlings gerespekteer het, was uitbuiting en onteiening 'n wrede werklikheid. Groot stukke grond is opgekoop en verhuur vir persoonlike gewin of vir die instandhouding van die Romeinse leër (kyk Fiensy 1991:79).

Hierdie koloniale oorheersing en onderdrukking. sou noodwendig stres by mense veroorsaak het. Daarom volg dit logies dat geestesversteurdheid/demoniese besetenheid so 'n prominente plek onder die gemeenskap inneem. Hollenbach (1982), Myers 
(1988:141-152, 1992:1-13), Waetjen (1989:113-119), Davies (1993:2) en Crossan (1996:92) wys ook op die verband tussen onderdrukking en demoniese besetenheid. Die klassieke voorbeeld ter illustrasie hiervan is Markus 5:1-20. (die besetene van Gerasa). Die demoon se naam, Legio, verwys na die Romeinse kolonialisme van Palestina met die gepaardgaande ekonomiese uitbuiting, politieke onderdrukking en sosiale ontwrigting. Deur die bose geeste uit te dryf en in die varke in te stuur en in die see te laat stort, het Jesus nie alleen sy mag oor 'kolonialisme' geillustreer nie, maar nok terselfdertyd die voedselbron van die Romeinse legioene vernietig. Romeinse imperialisme het beteken dat die Jode op sosiale vlak deur demone besete was. Deur die demone uit te dryf, het Jesus die Jode (simbolies) van die onderdrukking bevry (Van Eck 1995:311; Crossan 1996:93). Elke Joodse vryheidsvegter het daarvan gedroom dat die Romeine teruggedryf sal word in die Mediterreense see (Crossan 1996:92).

Ook in hierdie perikoop sien ons die ineengevlegtheid van die Mediterreense samelewingstruktuur: Die demoniese besetenheid is die gevolg van Romeinse onderdrukking (politiek). As gevolg van die besetenheid bly die man tussen die grafte en nie by sy familie nie (familiestrukturur). Die besetenheid het ook 'n effek op sy familie, die ontwrigting van die familielewe.

\subsection{Sosiale magsinstandhouding}

'n Saak wat beskou word as nou verwant aan die konsep van 'etikettering,' is die saak rondom 'sosiale magsinstandhouding'. Volgens Bourguignon (1976:53) en Rosen (1986:5-17) beteken dit dat aantygings van geestesversteurdheid, demoniese besetenheid en towery deur sosiaal dominante klasse gebruik kan word as 'n sosiale kontrolemaatreel. Hierdie aantygings is op 'n distansiëringstegniek gebaseer met die oogmerk om te diskrediteer, af te sonder, gemeenskaplike bande te ontken, en uiteindelik 'n aparte identiteit te vestig. Dit gebeur byvoorbeeld wanneer persone in godsdienstige gesagsposisies se verstaan van die gemeenskap bevraagteken word. In reaksie hierop sal hierdie leiers die persoon wat hulle bevraagteken, klassifiseer as duiwelbesete en in die proses sosiale beheer oor daardie persoon verkry, terwyl hulle terselfdertyd ook hulle eie verstaan van die samelewingstruktuur beskerm en in stand hou. (Van Eck 1995:309).

\subsection{Protes}

Demoniese besetenheid kan ook gesien word as 'n sosiaal aanvaarbare vorm van indirekte protes teen corheersing, of selfs as 'n ontvlugting van die oorheersing (Fanon 1963:290; Kiev 1964:218-219; Lewis 1971:72; Ward \& Beaubrun 1980:206). Davies 
(1995:37) sien sommige gevalle van demoniese besetenheid as 'n oorlewingsmeganisme, wat byvoorbeeld deur kinders teenoor ouers gebruik word, of deur vrouens teen hulle mans, wat dan daartoe dien dat gevoelens en eise uitgespreek word wat andersins gelaat sou gewees het. Op grond hiervan sê Van Eck (1995:309) dat sekere tipes demoniese besetenheid dus verstaan kan word as ontvlugting van, 'genesing' van, sowel as simptome van sosiale konflik. In 'n stresvolle situasie was demoniese besetenheid dus 'n sosiaal aanvaarde en erkende praktyk - 'n oorlewingsmeganisme wat as 'n uitlaatklep dien vir die stres wat deur die omstandighede veroorsaak is.

\subsection{Besetenheid as oorlewingsmeganisme ('coping mechanism')}

Verskeie kruis-kulturele studies het bewys dat duiwelbesetenheid 'n manier is waarop 'n sosiaal ondergeskikte individu reageer op bepaalde omstandighede (Davies 1995:81). Dit is ' $n$ persoon se manier om in sy of haar omstandighede (gewoonlik familiekonflikte) te oorleef - dus 'n oorlewingsmeganisme. Davies (1995:81) beskou dit as die rede waarom duiwelbesetenheid gewoonlik voorkom by vroue en kinders: hulle is ondergeskikte lede van 'n familiestruktuur. In die lig van antropologiese analise beweer Davies (1995:85) dat die meeste van die duiwelbesete persone uit wie Jesus demone gedryf het, hulleself in ondraaglike sosiaal ondergeskikte omstandighede (binne hulle familiegroepe) bevind het en dat dit waarskynlik is dat die meeste van hierdie persone vroue was (Luk 8:1-3).

Om van die duiwel besete te wees, was dus dikwels 'n oorlewingsmeganisme ('coping mechanism'), 'n manier van respons, eerder as 'n bonatuurlike gebeurtenis per se (Davies 1995:86).

\section{ONGESTELDHEID ('ILLNESS'), SIEKTE ('DISEASE'), HELING ('HEAL ING') EN GENESING ('CURE')}

In die Westerse samelewing, waar prestasie en selfvoorsiening 'n hoë kulturele waarde is, sou gesondheid gedefinieer kon word as 'die vermoë om daardie funksies te verrig wat die organisme in staat stel om homself in stand te hou.' Maar vanuit 'n mediesantropologiese perspektief word gesondheid verstaan as 'n toestand van welwees, soos gesien vanuit 'n bepaalde kulturele perspektief (Pilch 1995:319-320).

In die mediese antropologie word ongesteldheid ('sickness') as 'n sambreelterm gebruik om 'n realiteit te beskryf. 'Disease' en 'illness' word gebruik as verklarende terme om twee kante van hierdie een muntstuk, siekte te beskryf. 'Disease' is in die sfeer van die biomedisyne - 'n prognose kan gemaak word en terapie kan voorgeskryf word. 'Disease' tas individuele persone aan, 'n persoon word siek, 'n persoon is me- 
laats. Maar persone in die Mediterreense samelewing is altyd ingebed in 'n groep (vergelyk die konsep van diadiese persoonlikheid). Daarom word die term 'illness' in die mediese antropologie gebruik om die sosio-kulturele perspektief weer te gee, wat die sosiale en persoonlike belewenis van die siekte verdiskonteer.

Worsley (1982:327) sien 'illness' as 'n verklarende konsep wat die menslike waarneming, ervaring en interpretasie van sekere sosiaal waardelose toestande beskryf, wat 'disease' insluit, maar nie net daartoe beperk is nie. So is 'disease' 'n verklarende konsep wat abnormaliteite in die struktuur en/of funksie van die menslike organe beskryf.

'Curing' het betrekking op 'disease,' dit verwys na die geantisipeerde resultaat, met ander woorde, 'n poging word aangewend om effektiewe beheer te verkry van 'n ongestelde biologiese en/of psigologiese proses. 'Healing' is gerig op 'illness': 'n poging word aangewend om persoonlike en sosiale betekenis aan die lewe te gee, wat deur die 'sickness' weggeneem is. Die beswaar teen die moderne biomedisyne is dat dit slegs daarop gerig is om die 'disease' te 'cure', terwyl die pasiënt soek na 'n 'healing' van die 'illness' (Pilch 1995:320).

\section{DIE DOEL VAN WONDERVERTELLINGS: GENESINGS TER WILLE VAN GENESINGS?}

'n Wonderverhaal word nooit net ter wille van die wonder vertel nie; dit is altyd en prinsipieel instrumenteel in die hantering van 'n ander saak (Hills 1993:6). 'n Wondervertelling, ook die wondervertellings in die Nuwe Testament, is die outeur se weergawe en interpretasie van 'n bepaalde gebeure. Wanneer 'n outeur 'n storie vertel, word dit gedoen vanuit ' $n$ bepaalde perspektief en met ' $n$ bepaalde doel, hetsy die doel die cordra van inligting is, of die oorreding van die hoorder, of wat ook al. 'n Wondervertelling is 'n spraakhandeling, 'n linguistiese aksie, nie bloot 'n fisiese aksie nie. Daarom moet die leser van die teks bedag wees op die interpretasie van die outeur, asook op die doel waarvoor die outeur die wondervertelling aanwend (kyk Vorster 1986: 52-53). 


\section{GEVALLE STUDIES}

\subsection{Voorbeeld Een}

Die besetene van Gerasa (Mark 5:1-20)

Kommentaar ter illustrasie van die stresfaktor, asook die ineengeviegtheid van die Mediterreense samelewingstruktuur.

\begin{tabular}{|c|c|c|}
\hline Vers 1 & Tussen die grafte gebly & $\begin{array}{l}\text { Die demoniese besetenheid is die gevolg } \\
\text { van Romeinse onderdrukking (politiek) (kyk } \\
\text { Myers 1988:141-152; 1992:1-13; Waetjen } \\
\text { 1989:113-199; Davies 1993:2; Crossan } \\
\text { 1996:92). As gevolg van die besetenheid } \\
\text { bly die man tussen die grafte en nie by sy } \\
\text { familie nie (familiestruktuur) - die beseten- } \\
\text { heid het ook 'n effek op sy familie, die ont- } \\
\text { wrigting van die familielewe. Besetenes is } \\
\text { uit die gemeenskap geostraseer. }\end{array}$ \\
\hline Vers 6 & Voor Jesus neergeval & $\begin{array}{l}\text { Hierdie uitdrukking kom uit die beskerm- } \\
\text { heer onderdaan verhouding (Malina \& } \\
\text { Rohrbaugh 1992:208). Die neerbuig voor } \\
\text { 'n beskermheer was ' } n \text { tipiese manier } \\
\text { waarop 'n onderdaan om 'n guns gesmeek } \\
\text { het. Hier sien ons die ineengevlegtheid } \\
\text { tussen godsdiens en familieverhoudings, } \\
\text { die konsep beskermheer is aan die } \\
\text { familieverhoudings ontleen. }\end{array}$ \\
\hline Vers 9 & Legio & $\begin{array}{l}\text { ' } n \text { Latinisme: in die sosiale wereld van Mar- } \\
\text { kus, net een betekenis: ' } n \text { afdeling Romein- } \\
\text { se soldate (Myers 1988:191; Waetjen 1989: } \\
\text { 115). }\end{array}$ \\
\hline Vers 11 & Trop (agele) & Dikwels gebruik vir militêre rekrute. \\
\hline Vers 13 & Toegelaat (epetrepsen) & $\begin{array}{l}\text { Militère bevel (politieke struktuur) (Myers } \\
\text { 1988:191). }\end{array}$ \\
\hline Vers 13 & Op loop gesit (ormesen) & $\begin{array}{l}\text { Herinner aan troepe wat in 'n geveg instorm } \\
\text { (politieke struktuur) }\end{array}$ \\
\hline Vers 13 & $\begin{array}{l}\text { Op loop gesit teen die } \\
\text { hang af, in die see in. }\end{array}$ & $\begin{array}{l}\text { Romeinse soldate wat in die see stort, sou } \\
\text { beslis die droom van elke Joodse vryheids- } \\
\text { vegter gewees het (Crossan 1996:92). }\end{array}$ \\
\hline Vers 19 & $\begin{array}{l}\text { Gaan na jou huis, na jou } \\
\text { mense toe. }\end{array}$ & $\begin{array}{l}\text { Jesus herstel die familiebande, die belang- } \\
\text { rikste instelling van die Mediterreense } \\
\text { samelewingstruktuur. Die Grieks dui op sy } \\
\text { eie huis (familie), asook die wyer sosiale } \\
\text { netwerk (uitgebreide familie) waarvan hy } \\
\text { deel was (Malina \& Rohrbaugh 1992:208). } \\
\text { Die familiebande is herstel, dit sou lei tot } \\
\text { stresvermindering. }\end{array}$ \\
\hline
\end{tabular}




\begin{tabular}{|l|l|l|}
\hline Vers 19 & $\begin{array}{l}\text { Vertel hulle wat die Here } \\
\text { alles vir jou gedoen het } \\
\text { en dat Hy jou jammer } \\
\text { gekry het. }\end{array}$ & $\begin{array}{l}\text { Hier sien ons die taal van die godsdiens } \\
\text { wat ontleen is aan die familieverhoudings. } \\
\text { Jesus vestig die persoon wat genees is, se } \\
\text { aandag op die eintlike persoon aan wie die } \\
\text { eer toekom, naamlik aan God, die genadige } \\
\text { beskermheer (Waetjen 1989:119) }\end{array}$ \\
\hline
\end{tabular}

\subsection{Voorbeeld Twee}

\section{Die genèsing van ' $n$ melaatse man (Mark 1:40-45)}

\begin{tabular}{|c|c|c|}
\hline Vers 40 & $\begin{array}{l}\text { As } U \text { wil, kan } U \text { my gesond } \\
\text { maak. }\end{array}$ & $\begin{array}{l}\text { Melaatsheid is nie 'n kwessie van aan- } \\
\text { steeklikheid nie (Davies 1995:68) (kyk } \\
\text { volledige bespreking van melaatsheid } \\
\text { elders), maar van verontreiniging. Dus } \\
\text { is hierdie versoek 'n versoek om mede- } \\
\text { lye. Bes moontlik sien hierdie persoon } \\
\text { sy melaatsheid as God se straf op } \\
\text { sonde. Die veluitslag beteken hy is on- } \\
\text { rein, met die gevolg dat sy familie- } \\
\text { bande (familiestruktuur) daaronder sou } \\
\text { lei (vgl Malina \& Rohrbaugh 1992:100- } \\
\text { 101). Dit sou stres teweegbring. }\end{array}$ \\
\hline Vers 41 & $\begin{array}{l}\text { Jesus kry hom jammer en } \\
\text { sè: 'Ek wil, word gesond.' }\end{array}$ & $\begin{array}{l}\text { Jesus spreek ook die pasiënt se emo- } \\
\text { sie aan as Hy hom jammer kry. In 'n } \\
\text { tydperk wat gekenmerk word deur sterk } \\
\text { familiebande, sou die sosio-kulturele } \\
\text { aspek van die veluitsiag waarskynlik 'n } \\
\text { groter las wees om te dra as die bio- } \\
\text { chemiese aspek. }\end{array}$ \\
\hline Vers 44 & $\begin{array}{l}\text { Gaan wys jou vir die priester, } \\
\text { bring offers vir jou reiniging. } \\
\text { dit sal vir die mens die be- } \\
\text { wys wees dat jy rein geword } \\
\text { het. }\end{array}$ & $\begin{array}{l}\text { Gaan wys jou vir die priester (gods- } \\
\text { diens). Dit sou tot gevolg hè dat hy } \\
\text { ook weer huistoe kon gaan en die } \\
\text { familiebande (familiestruktuur) en } \\
\text { gemeenskapsbande (uitgebreide } \\
\text { familie) weer opneem. Die beteken } \\
\text { resosialisasie en outomatiese stres- } \\
\text { verliging. }\end{array}$ \\
\hline
\end{tabular}




\section{KONKLUSIE: WIE EN HOE HET JESUS GENEES?}

Jesus genees simptomaties, dit wil sê genesing is gefokus op die verligting of beheer van die simptome, 'n proses wat gerig is op die skepping van nuwe lewensin vir die pasiënt (Pilch 19:2:31).

Oor die vraag wie Jesus genees het en hoe sy genesings verstaan moet word, is Stevan Davies (1993:1) baie beslis: Jesus was 'n geloofsgeneser - 'n individu van wie ander mense glo dat Hy hulle gesond kan maak en wat, op grond van hulle geloof, hulle werklik gesond maak, of ten minste hulle simptome verlig, in so 'n mate dat die siekes daarvan oortuig is dat genesing plaasgevind het, of dat die natuurlike genesingsproses (wat in elk geval sou plaasvind), te danke is aan die (geloofs)geneser se rol.

Die vraag is watter simptome genees kan word deur 'n geneser wat, volgens die berigte in die evangelies, staatmaak op die individu se geloof in die geneser se vermoë om te genees. Watter tipe genesings sou 'n suksesvolle geneser kon bewerkstellig? Die antwoord hierop is psigosomatiese afwykings wat die gevolg is van stresvolle situasies. Dus kan Jesus se genesings beskryf word as 'psigoterapeuties' van aard (kyk Davies 1993:1; kyk ook Funk 1996:253).

Crossan (1996:79-80) maak 'n onderskeid tussen natuurwonders en eksorsismes en is van mening dat dit 'n growwe misverstand sal wees om die natuurwonders wat in die Bybel opgeteken is, letterlik te lees in plaas daarvan om dit metafories te verstaan as outoriteitsgelykenisse (authority parables), illustratief nie van Jesus se mag oor die natuur nie, maar van die dissipels se gesag in die kerk.

Daar is reeds daarop gewys dat in Lourdes, Frankryk en Fatima, Portugal (genesingsheiligdomme van Moeder Maria) asook in Epidaurus, Griekeland en Pergamum, Turkye (genesingsheiligdomme van Asklepius), die talle stelle krukke wat daar hang, die stille getuienis is van persone wat lam daar aangekom het en as gesonde mense daar uitgeloop het. Tog is daar geen teken van kunsmatige ledemate wat in hierdie heiligdomme agtergelaat is nie. Crossan (1996:81) gebruik hierdie feit om daarmee tot die volgende konklusie te kom: Geloof genees! Sekere siektes, vir sekere persone, onder sekere omstandighede kan genees word - vir 'n heiden in Epidaurus, vir 'n Christen in Lourdes, vir 'n Hindu in Henares, ensovoorts: Maar slegs sekere siektes, slegs vir sekere persone en slegs onder sekere omstandighede. En dit is presies wat Jesus gedoen het toe Hy by herhaling gesê het: 'Jou geloof het jou gered.' Dus, mense het na Jesus toe gekom om genees te word en sommige is wel genees.

Crossan (1996:84) sê dat dit die begin van wysheid mag wees as ons besef dat die wêreld van die Bybelverhaal in baie opsigte nie ons wêreld is nie (Crossan 1996:84). Hy illustreer dit met die voorbeeld van melaatsheid: die probleem met melaatsheid is dat dit openinge in die liggaam laat ontstaan, anders as die natuurlike openinge, met die 
gevolg dat die grense verbreek word. Die melaatse word dus nie net sosiaal as 'n probleem gesien as gevolg van mediese besmetting nie, maar as gevolg van simboliese be'smetting. Die afbreking van die liggaam se grense simboliseer ' $n$ bedreiging vir die integriteit en sekuriteit van die gemeenskap as geheel (vgl Lev 13:45-46).

Die feit dat die persoon in afsondering moes lewe en buite die kampplek moes bly, verwoord die gemeenskap se siening van 'n melaatse persoon. Wat Jesus gedoen het, was om hierdie uitgeworpene weer binne die gemeenskap te verwelkom. Hierdie welkom tuis was genesing (Crossan 1996:85). Jesus weier om te konformeer met die heersende sanksies teen siek persone. Hy aanvaar nie die persoon se siekte as rituele onreinheid nie. Deur die melaatse terug te verwelkom in die gemeenskap van God, het Jesus 'n uitdaging tot die gemeenskap se grensbewakers gerig (vgl Mark 1:44) en Homself as nuwe en alternatiewe grensbewaker gevestig. Dit bring Jesus noodwendig in botsing met die priesters en die tempel, wat die amptelike grensbewakers was.

Crossan (1996:88) definieer ' $n$ wonder nie soseer as 'n verandering in die fisiese wêreld nie, maar as 'n verandering in die sosiale wêreld. 'n Wonder is nie 'n periodieke inbreuk in 'n geslote natuurlike bestel nie. Dit gaan hier nie oor wat God kan doen (God se almag) nie, maar oor die wyse waarop God wel werk. Die bonatuurlike of goddelike is nie iets wat sporadies of tydelik deur die normale oppervlakte van die natuurlike of menslike wêreld breek nie. Dit is eerder vergelykbaar met die permanent verskuilde maar onophoudelike hartklop van die natuurlike. Dit is teenwoordig vir hulle wat dit deur die oog van geloof sien en met die oor van geloof hoor. Die teenwoordigheid en ingryping van God moet nie net waargeneem word in die krakies van die natuurlike bestel nie, maar eerder as alomteenwoordig, binne daardie natuurlike bestel (Crossan 1996:96).

Bate (1995:15) gebruik die term 'coping-healing.' Wanneer hy na kerke verwys waarin geloofsgenesing ' $n$ sentrale deel van hulle bediening uitmaak, gebruik hy die term 'coping-healing churches' en 'coping-healing phenomenon' (Bate 1995:15). Hy sê dan The addition of the word 'coping' renders the topic more neutral since finding ways and means of coping with reality may be experienced subjectively as healing but may not necessarily be that.

Hoewel grootliks met Bate saam gestem word, kan daar die volgende verduidelikeride kommentaar op sy stelling dat die genesing dalk wel subjektief as genesing ervaar kan word, maar dat dit nie noodwendig genesing is nie, gelewer word. Bate is reg, mits hy bedoel dat dit vanuit 'n mediese en biologiese gesigspunt nie noodwendig genesing is nie. Maar om die saak so te beoordeel, mis ons die punt. Vir die pasiēnt wat (subjektief) genesing ervaar, is dit 'n realiteit, net so 'n realiteit as wat dit vir die pasiënt is wat genesing beleef as die effektiewe kontrole van 'n biologiese proses (kyk Kleinman 1980:82). 
Pilch (1996:208) sê die volgende oor bogenoemde stelling van Bate: Per definisie sluit 'healing' (genesing) 'coping' in. Die frase 'coping-healing' is dus 'n toutologie. Pilch is ook van mening dat dit nie korrek is nie om te sê some ways and means of coping with reality may not necessarily be that (Bate 1995:150). Volgens mediese antropologie vind genesing ('healing') in alle gevalle plaas. 'Healing' vloei voort uit die feit dat die pasiënt nuwe betekenis in die lewe gevind het. Daarenteen vind 'curing' (die effektiewe beheer van 'n ongestelde biologiese en/of psigologiese proses) selde plaas (kyk Pilch 1996:208).

Die term bemagtigingsgenesing kan eerder gebruik word. Jesus se genesings in 'n moderne samelewing en hedendaagse Afrikaans kan omskryf word met die term bemagtigingsgenesing: Jesus 'bemagtig' mense om weer te oorleef; Hy gee nuwe sin en betekenis aan mense se lewe. Maar die Geneser betaal 'n prys daarvoor as Hy geëtiketteer word as 'n 'vriend van tollenaars en sondaars' (Matt 11: 19). Die genesings van Jesus is nie wondergenesings in die sin van 'n bonatuurlike ingryping van God in die fisiese wêreld nie, dit is eerder God se ingryping in die sosiale leefwêreld en lewens van mense. God het deur die genesings van Jesus in mense se lewens teenwoordig geword. Mense is genees deurdat God in 'nobodies' se lewens teenwoordig geword het: in die lewens van sondaars, straatvrouens, melaatses, en ander sosiaal uitgeworpenes.

Dit is moontlik dat God ook vandag wondergenesings verrig, maar dan genesings soos hierbo verstaan. Dit lyk nie of God vandag 'n ledemaat langer laat word of 'n kwaadaardige gewas cornag laat verdwyn nie. God laat nie 'n VIGS pasiënt (oornag) genees nie. God roep mense om as medici instrumente in sy hand te wees. Maar meer nog, God vira van gelowiges om instrumenteel te wees daarin om mense wat in nood is, sosiaal uitgeworpenes volgens vandag se standaarde, deur hulle medemens iets te laat beleef van God se liefde vir hulle en aanvaarding van hulle.

\section{Literatuurverwysings}

Bate, S C 1995. Inculturation and healing. Pietermaritzburg: Cluster Publications.

Bourguignon, E 1976. Possession. San Francisco: Chandler and Sharp.

Chiat, M J 1981. First-century synagogue architecture: Methodological problems, in Gutmann 1981:49-60.

Crossan 1996. Who is Jesus? Answers to your questions about the historical Jesus.

New York: Harper Collins.

Davies, S 1993. Whom Jesus healed and how. The Fourth $R$ 6/2, 1-11.

1995. Jesus the healer. London: SCM Press. 
Depue, R A \& Monroe, S M 1986. Conceptualization and measurement of human disorder in life stress research: The problem of chronic disturbance. Psychological Bulletin 99, 36.

De Villiers, P G R 1986. Jesus and the Divine Man tradition: Miracles in the world and time of the New Testament, in De Villiers, P G R (ed), Healing in the name of God. Pretoria: C B Powell Bybelsentrum, Universiteit van Suid-Afrika.

Engelbrecht, J 1986. The blind can see, the lame can walk, the deaf hear: Miracle workers and their miracles in the New Testament, in De Villiers, P G R (ed), Healing in the name of God. Pretoria: C B Powell Bybelsentrum, Universiteit van Suid-Afrika.

Fanon, F 1963. The wretched of the earth. New York: Ballantine.

Fiensy, D A 1991. The social history of Palestine in the Herodian Period. Lewiston, NY: Edwin Mellen. (Studies in the Bible and early Christianity 20.)

Funk, R W 1996. Honest to Jesus: Jesus for a new millenium. New York: Harper Collins.

Funk, R W (ed) 1998. The acts of Jesus: The search for the authentic deeds of Jesus. San Fransisco: Harper Collins.

Hills, J 1993. Jesus' miracles in history and tradition history. Jesus Seminar Papers, March 1993.

Hollenbach, P W 1982. Jesus, demoniacs, and public authorities: A socio-historical study. JAAR 49, 507-588.

Horsley, R A 1994. The historical Jesus and archaeology. of the Galilee: Questions from historical Jesus research to archaeologists. SBL 1994 Seminar Papers. Atlanta: Scholars Press.

Horsley, R A \& Hanson, J S 1985. Bandits, prophets and messiahs: Popular movements in the time of Jesus. Minneapolis: Winston.

Kiev, A (ed) 1964. Magic, faith and healing: Studies in primitive psychiatry today. New York: Free Press.

Kleinman, A M 1980. Patients and healers in the context of culture. Berkeley: University of Califomia Press.

Lewis, I M 1971. Ecstatic religion: An anthropological study of possession and Shamanism. Baltimore: Penguin.

Malina, B J 1993. Windows on the world of Jesus: Time travel to ancient Judea. Louisville: John Knox.

Malina, B J \& Neyrey J H 1988. Calling Jesus names: The social value of labels in Matthew. Sonoma: Polebridge Press. 
Malina, B J 1991a. First-century personality: Dyadic, not individualistic, in Neyrey 1991:67-96.

Malina, B J \& Neyrey J H 1991b. Conflict in Luke-Acts: Labelling and deviance theory, in Neyrey 1991: 97-124.

Malina, B J \& Rohrbaugh, R L 1992. Social science commentary on the synoptic gospels. Minneapolis: Fortress.

Matthews, V H 1988. Manners and customs in the Bible. Peabody, MA: Hendrickson.

Meyers, E M 1981. Ancient Gush Halav (Giscala), Palestinian synagogues and the eastern Diaspora, in Gutmann 1981:61-78.

Myers, C 1988. Binding the strong man: A political reading of Mark's story of Jesus. New York: Orbis.

Oakman, D E 1986. Jesus and the economic questions of his day. New York: The Edwin Mellen Press.

Pilch, J J 1992. Understanding healing in the social world of early Christianity. BTB 22/1, 26-33.

1995. Insights and models from medical anthropology for understanding the healing activity of the historical Jesus. HTS 51/2, 314-337.

1996. Resensie van Bate, S C 1995, Inculturation and healing. Pietermaritzburg: Cluster Publications. HTS 52/1, 205-210.

Rousseau, J J 1992. Jesus in the world of exorcism. Jesus Seminar Papers, October 1992.

Rosen, G 1986. Madness in society: Chapters in the historical sociology of mental illness. Chicago: University of Chicago Press.

Sanders, E P 1985. Jesus and Judaism. Philadelphia: Fortress Press.

Van Aarde, A G 1994a. Kultuurhistoriese agtergrond van die Nuwe Testament. Pretoria: Kital.

1994b. A silver coin in the mouth of a fish (Mt 17:24-27): A miracle of nature, ecology, economy and the politics of holiness, in Van Aarde, A G 1994, God-with-us: The dominant perspective in Matthew's story, and other essays, 204 228. Pretoria: University of Pretoria. (HTS Suppl 5.)

Van Eck, E 1995. Galilee and Jerusalem in Mark's story of Jesus: A narratological and social scientific reading. Pretoria: University of Pretoria. (HTS Suppl 7.)

Vermes, G 1973. Jesus the Jew. London: Collins.

Vorster, W S 1986. On miracles and miracle stories: From the earthly Jesus to the written text, in De Villiers, P G R (ed), Healing in the name of God. Pretoria: C B Powell Bybelsentrum. Universiteit van Suid-Afrika. 
Waetjen, H C 1989. A reordering of power: A socio-political reading of Mark's gospel. Minneapolis: Fortress.

Ward, C \& Beaubrun, M H 1980. Psychodynamics of demon possession. Journal for the Scientific Study of Religion 19/2, 201-207.

Worsley, P 1982. Non-Western medical systems. Annual Review of Anthropology 11, 315-348. 